\title{
Beyond The Second Reconstruction: C. Vann Woodward's Concept of the Third Reconstruction in the South
}

Hanes Walton, Jr., Josephine A.V. Allen, Sherman C. Puckett, and Donald R. Deskins, Jr.

Best known for the innovative historical and analytical concept of the "Second Reconstruction," Professor C. Vann Woodward is much less known for his other related and linked concept the "Third Reconstruction." Moreover, this latter concept is clearly not as well understood, described, and explained as was the initial one. Yet, it exists. Professor Woodward in the updated third edition of his classic, The Burden of Southern History (which came out initially in 1968, 1991, 1993, and 2008 with an added Postscript in April of 1968 after the assassination of Reverend Doctor Martin Luther King), discusses the "Third Reconstruction" in Chapter Eight entitled: "What Happened to the Civil Rights Movement" (Woodward 2008, 186).

Writing in that Postscript, Professor Woodward noted upon Doctor King's death that "it is true that as young as he was at the time of his death King was still more identified with the Second Reconstruction, which had largely run its course, than he had yet come to be with the Third Reconstruction, which was struggling to be born" (Woodward 2008, 186). This major comment in his writings and others dealing with this same concept that are scattered in the same work does not hesitate to indicate that this noted historian of southern history was moving intellectually and conceptually beyond his original and highly influential and impactful "Second Reconstruction" concept. Embedded in his vision of a "Third Reconstruction" was a very strong belief that the South was ever changing and not always in a linear fashion (Woodward 1960). On this matter of change, Professor Woodward himself commented that:

What the perspective of years will lend to the meaning of change we cannot know. We can, however, recognize and define the area and extent of change. I shall even be so bold as to maintain that recent changes are of sufficient

HANES WALTON, JR., is a professor of political science at the University of Michigan. JOSEPHINE A.V. ALLEN is a professor emerita of policy analysis and management at Cornell University and professor of social welfare policy in the College of Community and Public Affairs at Binghamton University. SHERMAN C. PUCKETT is the retired director of geographic information systems in Wayne County, Michigan. DONALD R. DESKINS, JR., is professor emeritus of sociology at the University of Michigan.

The American Review of Politics, Vol. 32, Summer, 2011: 105-130

(c)2011 The American Review of Politics 
depth and impact to define the end of an era of Southern History (Woodward 1957, 11).

In addition, this statement on the Third Reconstruction tells reveals that Professor Woodward was trying to date and define clearly these two times periods. Since the First Reconstruction had a specific periodization and he had given the Second Reconstruction a time frame, it would be obvious that the next period had to have a time frame. But there was a much more important factor: goals and objectives that he had for his beloved South. If certain goals and objectives did not come to fruition in the First or the Second time frame, it would be essential for these things to come in the next time period. And each one of these time frames had to have some event, moment or turning point that would signal and cue his readers to the fact that another period had arrived and/or was in the throes of arriving. Moreover, Woodward championed the idea that the South would inevitably shake off and relieve itself of its burden, and, in this process of transformation, would become its better self. This driving characteristic was at the very core of Professor Woodward's thesis and it had been shaped by his understanding and analysis of what had happened in the First Reconstruction.

In a book of essays written in Woodward's honor, several of his former doctoral students comment on this drive and his continual intellectual growth. Professors J. Morgan Kousser and James McPherson note that:

\begin{abstract}
Woodward's range of knowledge and the flexibility and sheer playfulness of his mind have cast up so many new and striking ideas that there are many 'Woodward theses'-some merely accepted, some repeatedly confirmed, some discarded, some challenged, some forcefully disputed, some discarded, some (in our view, unfortunately) ignored (Kousser and McPherson 1982, XXv).
\end{abstract}

But not only did his students see this change theme in his works, even his critics do so. One of Woodward's colleagues and co-authors, historian William Leuchtenburg writes on this point that another colleague noted:

When prominent critics pointed out an omission or flaw in his works, or disagreed with his conclusions, Woodward patiently explored the issue and did more research until he had either changed his mind or chose (to use a favorite word of his) to remain 'unrepentant' (Leuchtenburg 2008).

Thus, since change was a central core to his seminal ideas about the South as well as in his intellectual growth and progress, the question can be raised at this point, what role and/or function did it play in his conceptualizations, specifically in the concepts of the Second and Third Reconstructions? And more importantly, what can these innovative and periodized concepts tell us 
about (1) the dominant factor and object in these different stages of Reconstruction and about (2) the Southern African American and his emergent political and suffrage rights? Herein lay the subject matter of this paper as well as our reasons for proposing the intellectual groundwork and imagination for future scholars who want to work on and use Woodward's concept of the "Third Reconstruction."

\section{The Data and Methodology for the Concept: Third Reconstruction}

Of his prodigious works and seminal ideas, two of his students, Professors Kousser and McPherson, have written that "two major avenues of research toward which Woodward pointed the way either have not been much traveled or have only begun to attract other scholars" (Kousser and McPherson 1982, xxxii). The first avenue involves his 1960 the "Age of Reinterpretation" article with its thesis about the "age of free security," while the second avenue launches the quest and need for work in the area "of comparative history, and particularly of comparative Reconstruction," which he claimed was "a road that has not as yet been taken very far by very many American historians, except those studying slavery and antislavery" (Kousser and McPherson 1982, xxxii), but this two avenue typological assessment of his work is incomplete because the academic avenue set into motion by his dual Second and Third Reconstruction concepts are a road not yet taken. In point of fact, even in the book written by his doctoral students, there is not a single chapter devoted either to the First, Second or Third concepts of Reconstruction, much less a comparative analysis of the latter two. Seemingly, his students found nothing intellectually interesting about the concepts despite the fact that they had become quite popular in two major academic disciplines, history and political science (Valelly 2004).

In an edited volume with chapters written by his critics, one finds the same type of omission. Not a single chapter is devoted either in a singular or comparative fashion to either the First, Second or Third Reconstruction. The closest that this work comes is in the chapter written by Historian Howard Rabinowitz "More Than the Woodward Thesis: Assessing The Strange Career of Jim Crow." In this chapter, Professor Rabinowitz not only shows that "there were distinct stages in the subsequent developments of the three revised editions that appeared in the next twenty publishing seasons," but he also focuses on the three main contributions of Woodward's book, one of which is his concept of the Second Reconstruction (Rabinowitz 1997 184). He declares that of the three "contributions of Strange Career . . . the second is the concept of the Second Reconstruction as a way of gaining perspective on Reconstruction or, in Woodward's term, the 'First Reconstruction"” (Rabinowitz 1997, 184). Having indicated his focus on this concept, 
Professor Rabinowitz offers a detailed discussion and explanation of it beginning on page 191 in the chapter and continuing on through page 197, making it one of the longest scholarly coverages currently available (Rabinowitz 1997, 191-97).

Finally, there is the biography on Woodward by Professor John Herbert Roper, the editor of the critics' volume. Although there are no chapters on the First, Second or Third Reconstructions, nor any subsections of chapters devoted to any of them, one does find single and/or two sentence references on pages 247, 289, 290, and 291 (Roper 1987). Specifically, Chapter 7, "The Strange Career of Jim Crow, 1954-1955," does not offer any coverage and/ or analysis of the concept. Nor does Chapter 8, "The Burden of Southern History: Ironic Perceptions, Ironic Commitments, 1955-1965.” Surprisingly, it is the last Chapter 10, "The Gift," that offers the most pages of single sentence references. Hence, even in this first biography on Professor Woodward there is very little about this influential concept.

Collectively speaking, then, there is only brief mention and discussions in any of the current three sources; the book by his students, the book by his critics and the lone biography. Yet, when one goes searching for perhaps one of his most seminal ideas, there is little to be had from his colleagues, peers and critics despite the heavy and enduring use of it in both the discipline of history and political science. Hence, the purpose of our goes beyond an analysis of Professor Woodward's elusive, barely mentioned and hardly discussed concept known as the Third Reconstruction.

Thus, it is first essential and necessary to delineate, describe and explain Woodward's conceptualization of the First Reconstruction and then Second Reconstruction. None of the current academic and scholarly works at this writing does that. Therefore, we will have to undertake a content analysis of his works to collect his own rendering of these two background and preceding concepts. Once we have collected the major and key statements, references and discussions from Woodward's works on the First and Second Reconstructions, our next step will be to organize and structure such data so that we will have as much as possible a holistic conceptual portrait of each of these two enduring concepts. And using these distilled portraits, we will be able to not only understand each of these two concepts separately but also use each one to tell us about the Third one.

Once we have his rending of the first and second conceptualizations then it is possible to extrapolate from them insights, clues and suggestions to help us formulate and then further conceptualize the rather vague and imprecise concept the Third Reconstruction. Here, our inferential analysis and approach derived from an understanding of how Woodward put together these first two concepts can guide and assist us in the further exploration of his evolving third concept. And with these background concepts it might just 
be possible to generate a robust conceptualization for the first time of all three of these dramatic and dynamic stages of Reconstruction in the American South.

Thus, our basic data for structuring and organizing two of Woodward's three concepts and possibly building and structuring the third concept will be Woodward's own books and articles as well as some of the key secondary works on the man and his works. Admittedly, there is not much in the secondary sources and to an extent in his original sources. Moreover, in dealing with such theoretical concepts, it is necessary to reframe Woodward's ideas as analytical and logical concepts. Therefore, we are planning to place these analytical and logical concepts inside an empirical context to see if his logical concepts have any grounding in a quantitative fashion in the South. To undertake this empirical investigation and evaluation this study will collect election return data from the South using African American and White majority counties during the presidential primaries when African American Democratic and Republican presidential candidates ran in 1972, 1984, 1988, 2004, and 2008. And it is the last campaign that will allow us to use the same type of election return data from the South in the general election. Findings from both the primary and general elections will provide empirical based insights about how well the Second and Third Reconstruction concepts are becoming accepted in the region by both groups of voters. Thus, the second source of the data for this article will be election return data at the county-level in the eleven states of the old South.

In addition, the recent 2008 presidential election and its African American winner would obviously be a keystone characteristic moment and date inside the Third Reconstruction concept that we will need to begin with a quantitative analysis of this unique and rare historical event in the nation and the South instead of our proposed initial conceptual analysis. First, a quantitative analysis will enable one to see if any patterns and trends emerge in these African American presidential candidacies in the major party's presidential primaries. And secondly, if such empirical facts evolve then it might be quite useful to use these patterns and trends to assess and evaluation and illuminate the nature and scope and significance of not only the Third Reconstruction concept but the other two as well. With this approach, we can establish some empirical tendencies that hopefully will be thoughtprovoking enough to generate new work with Woodward ideas.

And in terms of the methodologies used in this article, there will be a content analysis of the relevant books and articles of the theorists, Woodward and his observers and critics. Secondly, in order to summarize and manage the election return data, the paper will employ the standard descriptive statistics and the appropriate visual statistics to present and graphically 
compare and contrast the different and diverse findings evolving from the different states and the two categories of counties in the region.

Overall, the purpose of this work is to determine how well these three conceptualizations of Reconstruction in the South as advanced by Professor Woodward enable us to understand and grasp the strengths and weaknesses of three different reform efforts in the region and whether there will be in the future the need for a "Fourth Reconstruction."

\section{Vann Woodward's Concept of the Third Reconstruction as Seen from a Quantitative Perspective on African American Presidential Candidates}

Professor Woodward seems to place the Second Reconstruction in the period marked by the Supreme Court Brown v. Board of Education decision in May 17, 1954 through 1966 (Woodward 2008, 173). Although Woodward is not quite clear in his writings when the Third Reconstruction started, he suggests that it was struggling to be born at the time of his death on April 4, 1968 (Woodward 2008, 186). Despite this uncertainty, Woodward was nevertheless discussing it and a central feature has to be the African American winner in 2008. Thus, a quantitative rending of this central feature might just help us in our theory building efforts here.

The theoretical conceptualization of the Third Reconstruction appeared in a 1967 article for Harper's Magazine and it later surfaced in 1968 in the second edition of his book of essays, The Burden of Southern History as chapter eight entitled: "What Happened to the Civil Rights Movement." In that magazine essay, Woodward contended that:

It may be that in due course, say on the eve of the Third Reconstruction, some enterprising historian will bring out a monograph on the Compromise that ended the Second Reconstruction, entitled perhaps The Triumph of Tokenism. And he may judiciously set forth the background of how the people wearied of the annual August ghetto riots, and the inevitable call for troops, of the farcical war on poverty and all the corruption and the squandering of public funds, of the rise of racial demagogues, and their shameless antics in New York, Baltimore, Atlanta, and Los Angeles. . . . Then, observing that since in the first instance the cycle ran from 1865 to 1877 and in the second from 1954 to 1966, our future historian may tentatively hypothesize that a baker's dozen years is par for the course (Woodward 2008, 173).

Learning from Woodward's conceptualization of the First and Second Reconstruction, we know that some major reform movement launched by one or more branches of the federal government to rectify some new or continuing breaches in the South of African American constitutional rights. 
Secondly, we learn from the above passage that this reform effort will probably last some twelve years before it runs its course.

After these opening remarks and comments Woodward adds to his evolving concept of the Third Reconstruction by raising the pertinent question: "How long before the country would be prepared to face up to a Third Reconstruction - which is what a realistic solution of the new national problems really amounted to—remained to be seen.” He continues:

\begin{abstract}
and whether much of the spent momentum and the old élan of past crusades would be marshaled and how many veteran leaders could be enlisted to get an entirely new program off the ground was problematical. The White House Conference of June, 1966, which was designed to do just these things, failed of its purpose.
\end{abstract}

Thus, he concludes with the perceptive suggestion that "veterans of the Second Reconstruction and planners of a Third would do well to face up to the fact that the one is now over and the other is still struggling to be born" (Woodward 2008, 178). While these combined remarks and comments are quite helpful, they still do not provide the beginning of the Third Reconstruction.

Nevertheless, help arrives from elsewhere in his writing. He tells us that there are "two distinctive features of the Second Reconstruction: (1) the predominance of the Negro, and (2) the predominance of youth." This suggests that part of the story and characteristic of any Third Reconstruction will be the "Negro" and the South. Thus, one needs to launch an investigation into the recent political behavior of the African American electorate in the South and the responses of the white South to this recent political behavior. The recent presidential elections where African American presidential candidates were running for major party nominations offer the events necessary to make a quantitative assessment. Therefore, whatever the nature and scope of the Third Reconstruction might become and the length and attainment of any reforms as a consequence of it, it will have embedded in it, the impact and influence of African American presidential candidates for the nominations of the two major political parties in the South (Walton et al. 2010, 167-86).

Although African American presidential candidates seeking major party nominations began with Congresswoman Shirley Chisholm's 1972 campaign for the Democratic party nomination, currently there is not available county-level data from that campaign. Thence, we have moved to Reverend Jesse Jackson's two campaigns in 1984 and 1988. Figure 1 shows how candidate Jackson fared in the African American majority counties in the four southern states that held presidential primaries in 1984. Jackson both won and lost some of these counties. He won nine in Alabama and lost 
112 | H. Walton, Jr., J.A.V. Allen, S.C. Puckett, and D.R. Deskins, Jr.

Figure 1. Performance of Jesse Jackson in African American Majority Counties of the South, 1984 Presidential Primaries

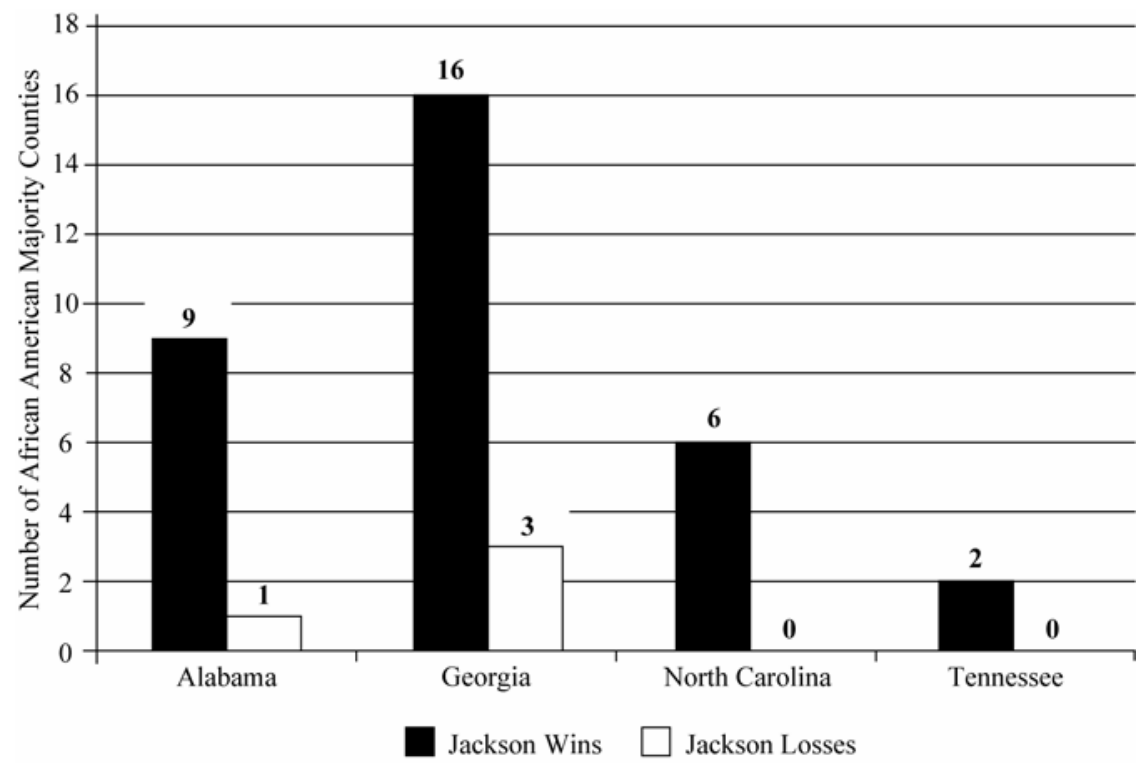

Figure 2. Performance of Jesse Jackson in White Majority Counties of the South, 1984 Presidential Primaries

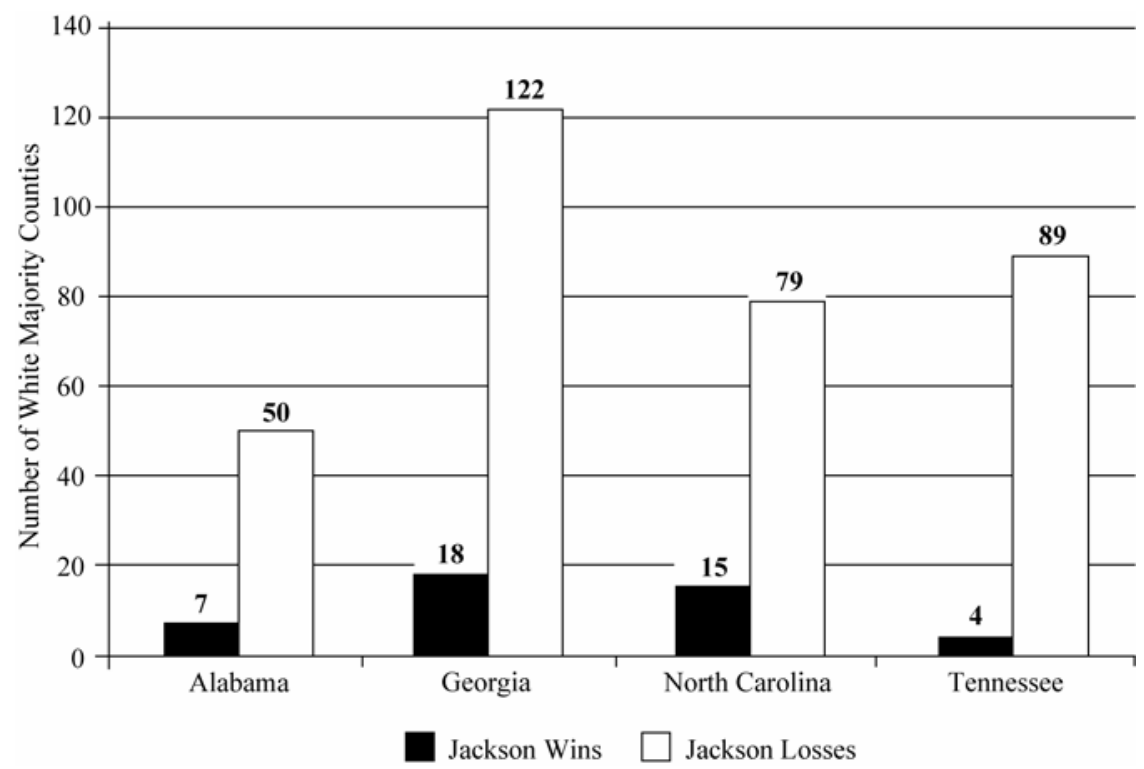


one, while in Georgia he won sixteen and lost three but won six in North Carolina and two in Tennessee but lost one in these two states.

Figure 2 shows the number of white majority counties that Jackson won and lost in four of the southern states in 1984. In Alabama, he won seven and lost fifty, while in Georgia he won eighteen and lost 122; in North Carolina he won fifteen and lost seventy-nine and in Tennessee he won four and lost eighty-nine. Thus, the pattern across the South was that he lost more white majority counties than he won. And when these two Figures are compared and contrasted, Jackson in 1984 won more white majority counties in Alabama, Georgia and Tennessee than he did African American counties. Just the opposite was true in the state of North Carolina.

Table 1 (1984) reveals that Jackson won about 89 percent of the African American counties but only about eleven percent (10.8\%) of the white majority counties. But in actual totals, Jackson won more white majority counties than he did the African American majority counties. Here, we see in empirical terms at the county-level in the South how the African American and white electorates initially responded to an African American presidential candidate. Simply put, the white electorate opposed such a candidate in these four southern states.

\section{Table 1. Performance of Jesse Jackson in Counties of the South 1984 Presidential Primaries}

\begin{tabular}{|c|c|c|c|c|c|c|}
\hline \multirow[b]{2}{*}{ State } & \multirow{2}{*}{$\begin{array}{c}\text { Racial } \\
\text { Majority }\end{array}$} & \multicolumn{2}{|c|}{ Counties Won } & \multicolumn{2}{|c|}{ Counties Won } & \multirow{2}{*}{$\begin{array}{c}\text { Total } \\
\text { Number of } \\
\text { Counties }\end{array}$} \\
\hline & & Number & Percent & Number & Percent & \\
\hline \multirow[t]{3}{*}{ Alabama } & Black & 9 & $90.0 \%$ & 1 & $10.0 \%$ & 10 \\
\hline & White & 7 & $12.3 \%$ & 50 & $87.7 \%$ & 57 \\
\hline & Total & 16 & $23.9 \%$ & 51 & $76.1 \%$ & 67 \\
\hline \multirow[t]{3}{*}{ Georgia } & Black & 16 & $84.2 \%$ & 3 & $15.8 \%$ & 19 \\
\hline & White & 18 & $12.9 \%$ & 122 & $87.1 \%$ & 140 \\
\hline & Total & 34 & $21.4 \%$ & 125 & $78.6 \%$ & 159 \\
\hline North & Black & 6 & $100 \%$ & 0 & $0 \%$ & 6 \\
\hline \multirow[t]{2}{*}{ Carolina } & White & 15 & $16.0 \%$ & 79 & $84.0 \%$ & 94 \\
\hline & Total & 21 & $21.0 \%$ & 79 & $79.0 \%$ & 100 \\
\hline \multirow[t]{3}{*}{ Tennessee } & Black & 2 & $100 \%$ & 0 & $0 \%$ & 2 \\
\hline & White & 4 & $4.3 \%$ & 89 & $95.7 \%$ & 93 \\
\hline & Total & 6 & $6.3 \%$ & 89 & $93.7 \%$ & 95 \\
\hline \multicolumn{2}{|c|}{ Black County Totals } & 33 & $89.2 \%$ & 4 & $10.8 \%$ & 37 \\
\hline \multicolumn{2}{|c|}{ White County Totals } & 44 & $11.5 \%$ & 340 & $88.5 \%$ & 384 \\
\hline \multicolumn{2}{|c|}{ Grand Totals } & 77 & $18.3 \%$ & 344 & $81.7 \%$ & 421 \\
\hline
\end{tabular}


114 | H. Walton, Jr., J.A.V. Allen, S.C. Puckett, and D.R. Deskins, Jr.

Figure 3. Performance of Jesse Jackson in African American Majority Counties of the South, 1988 Presidential Primaries

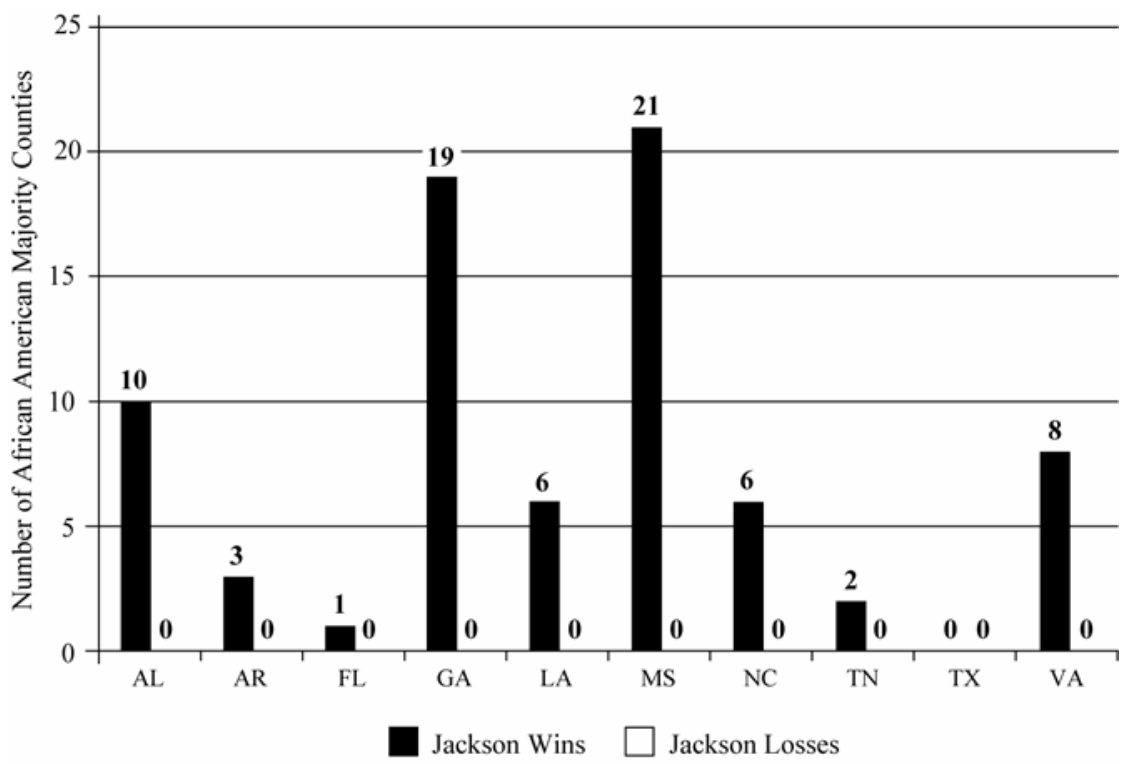

Figure 4. Performance of Jesse Jackson in White Majority Counties of the South, 1988 Presidential Primaries

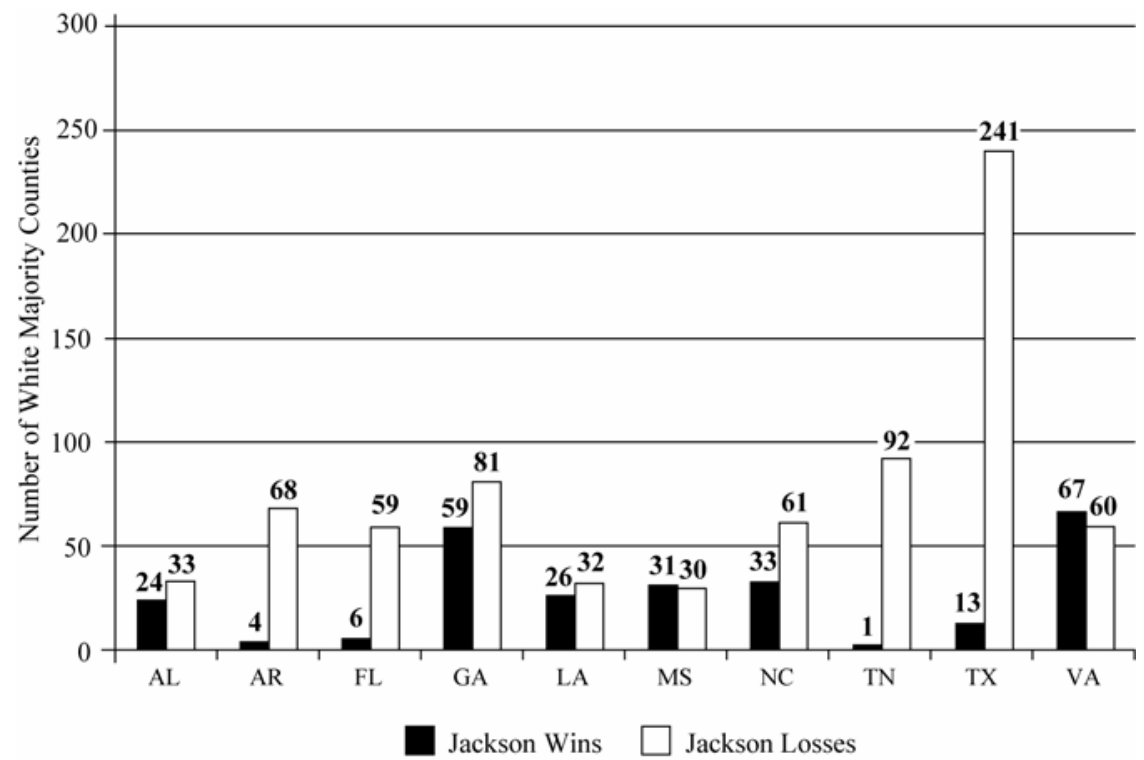


However, Jackson ran again in 1988. This time ten of the eleven southern states held presidential primaries. Only South Carolina did not hold a presidential primary. Figure 3 (1988) reveals the numbers of counties that Jackson won and lost in these eleven states. The pattern and trend is quite clear. Jackson won every African American majority county in all ten states. Moreover, when comparing his performances in the four states in 1984 to the same four states in 1988 he improved in terms of the number of counties won in only two of the four states, Alabama and Georgia because he had maxed out in North Carolina and Tennessee in 1984 anyway.

Figure 4 (1988) shows the white majority counties in the South won by Jackson in the 1988 Democratic presidential primaries. Only in two of the ten states, Mississippi and Virginia, did Jackson win more white majority counties than he lost. In the other eight states he lost more white majority counties than he won. Clearly, the majority of the counties in the South were not in his electoral coalition but he did improve over his performance four years before.

Table 2 (1988) reveals that Jackson won one hundred percent of the African American majority counties, which was about a ten percent improvement over his 1984 performance. In addition, he won one-fourth (25.9\%) of the white majority counties and lost some three-fourths (74.1\%) of said counties. This too was nearly a fifteen percent improvement over his 1984 performance. White support for Jackson had grown.

In the interim presidential primaries, Alan Keyes, an African American Republican ran and neither one of his efforts eventuated into the winning of a single county anywhere in the South (Walton and Lester 1999). Nor did former U.S. Senator Carol Moseley Braun win any counties in her 2004 run but the Reverend Al Sharpton did win one county in his 2004 run for the Democratic Party nomination. However, all of that would change with U.S. Senator Barack Obama's (D-IL) race in 2008 (Deskins et al. 2010).

Figure 5 (2008) shows the number of counties that Senator Barack Obama won and lost in the African American majority counties in all eleven of the southern states (Texas shows no victories or losses simply because by the year 2008 there were no African American majority counties in the state). Hence, only in Arkansas did Senator Obama lose an African American majority county and this is due in part to the fact that Arkansas was the adopted "Home State" of Senator Hillary Clinton, his opposition (Walton 2000).

Figure 6 (2008) shows the number of counties which Senator Obama won in the white majority counties in 2008 in all eleven southern states. The pattern and trend in this empirical data is that in two of these states, Georgia and Virginia, Senator Obama won more white majority counties than he lost while in the other nine states he lost more counties than he won. Thus, to put 
116 | H. Walton, Jr., J.A.V. Allen, S.C. Puckett, and D.R. Deskins, Jr.

Table 2. Performance of Jesse Jackson in Counties of the South 1988 Presidential Primaries

\begin{tabular}{|c|c|c|c|c|c|c|}
\hline \multirow[b]{2}{*}{ State } & \multirow{2}{*}{$\begin{array}{c}\text { Racial } \\
\text { Majority }\end{array}$} & \multicolumn{2}{|c|}{ Counties Won } & \multicolumn{2}{|c|}{ Counties Won } & \multirow{2}{*}{$\begin{array}{c}\text { Total } \\
\text { Number o } \\
\text { Counties }\end{array}$} \\
\hline & & Number & Percent & Number & Percent & \\
\hline \multirow[t]{3}{*}{ Alabama } & Black & 10 & $100 \%$ & 0 & $0 \%$ & 10 \\
\hline & White & 24 & $42.1 \%$ & 33 & $57.9 \%$ & 57 \\
\hline & Total & 34 & $50.7 \%$ & 33 & $49.3 \%$ & 67 \\
\hline \multirow[t]{3}{*}{ Arkansas } & Black & 3 & $100 \%$ & 0 & $0 \%$ & 3 \\
\hline & White & 4 & $5.6 \%$ & 68 & $94.4 \%$ & 72 \\
\hline & Total & 7 & $9.3 \%$ & 68 & $90.7 \%$ & 75 \\
\hline \multirow[t]{3}{*}{ Florida } & Black & 1 & $100 \%$ & 0 & $0 \%$ & 1 \\
\hline & White & 6 & $9.2 \%$ & 59 & $90.8 \%$ & 65 \\
\hline & Total & 7 & $10.6 \%$ & 59 & $89.4 \%$ & 66 \\
\hline \multirow[t]{3}{*}{ Georgia } & Black & 19 & $100 \%$ & 0 & $0 \%$ & 19 \\
\hline & White & 59 & $42.1 \%$ & 81 & $57.9 \%$ & 140 \\
\hline & Total & 78 & $49.1 \%$ & 81 & $50.9 \%$ & 159 \\
\hline \multirow[t]{3}{*}{ Louisiana } & Black & 6 & $100 \%$ & 0 & $0 \%$ & 6 \\
\hline & White & 26 & $44.8 \%$ & 32 & $55.2 \%$ & 58 \\
\hline & Total & 32 & $50.0 \%$ & 32 & $50.0 \%$ & 64 \\
\hline \multirow[t]{3}{*}{ Mississippi } & Black & 21 & $100 \%$ & 0 & $0 \%$ & 21 \\
\hline & White & 31 & $50.8 \%$ & 30 & $49.2 \%$ & 61 \\
\hline & Total & 52 & $63.4 \%$ & 30 & $36.6 \%$ & 82 \\
\hline North & Black & 6 & $100 \%$ & 0 & $0 \%$ & 6 \\
\hline \multirow[t]{2}{*}{ Carolina } & White & 33 & $35.1 \%$ & 61 & $64.9 \%$ & 94 \\
\hline & Total & 39 & $39.0 \%$ & 61 & $61.0 \%$ & 100 \\
\hline \multirow[t]{3}{*}{ Tennessee } & Black & 2 & $100 \%$ & 0 & $0 \%$ & 2 \\
\hline & White & 1 & $1.1 \%$ & 92 & $98.9 \%$ & 93 \\
\hline & Total & 3 & $3.2 \%$ & 92 & $96.8 \%$ & 95 \\
\hline \multirow[t]{3}{*}{ Texas } & Black & 0 & $0 \%$ & 0 & $0 \%$ & 0 \\
\hline & White & 13 & $5.1 \%$ & 241 & $94.9 \%$ & 254 \\
\hline & Total & 13 & $5.1 \%$ & 241 & $94.9 \%$ & 254 \\
\hline \multirow[t]{3}{*}{ Virginia } & Black & 8 & $100 \%$ & 0 & $0 \%$ & 8 \\
\hline & White & 67 & $52.8 \%$ & 60 & $47.2 \%$ & 127 \\
\hline & Total & 75 & $55.6 \%$ & 60 & $44.4 \%$ & 135 \\
\hline \multicolumn{2}{|c|}{ Black County Totals } & 76 & $100 \%$ & 0 & $0 \%$ & 76 \\
\hline \multicolumn{2}{|c|}{ White County Totals } & 264 & $25.9 \%$ & 757 & $74.1 \%$ & 1021 \\
\hline \multicolumn{2}{|c|}{ Grand Totals } & 340 & $31.0 \%$ & 757 & $69.0 \%$ & 1097 \\
\hline
\end{tabular}


Figure 5. Performance of Barak Obama in African American Majority Counties of the South, 2008 Presidential Primaries

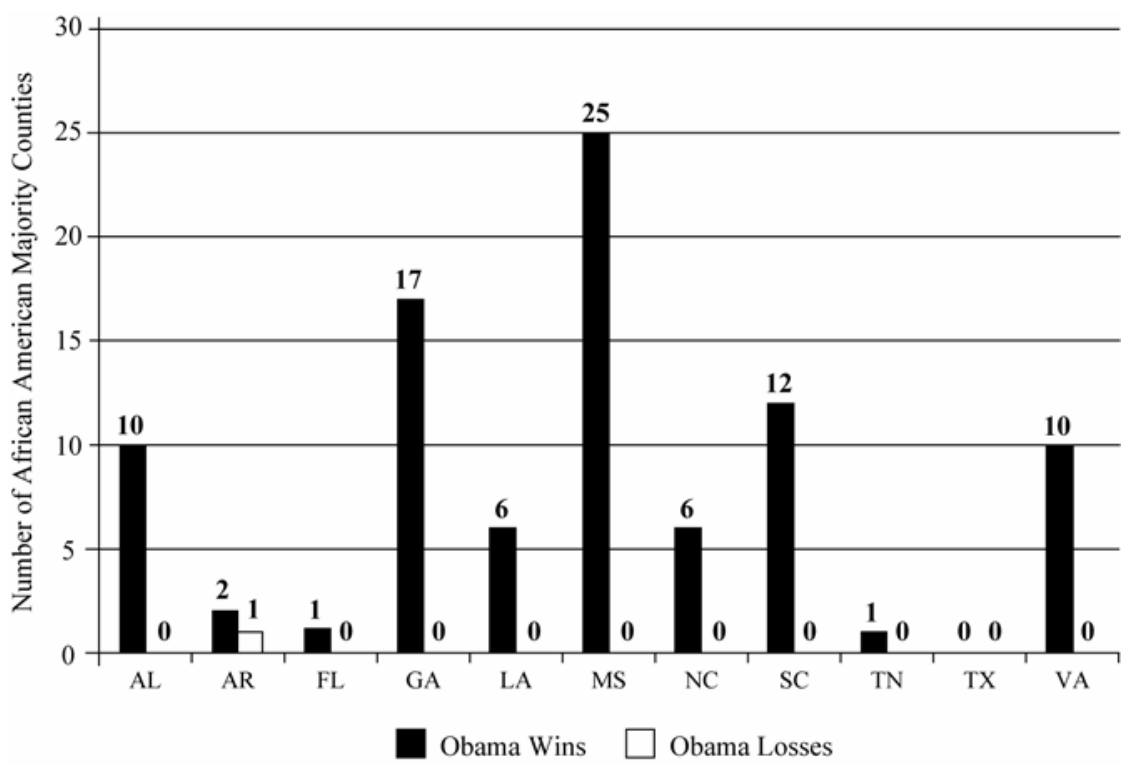

Figure 6. Performance of Barak Obama in White Majority Counties of the South, 2008 Presidential Primaries

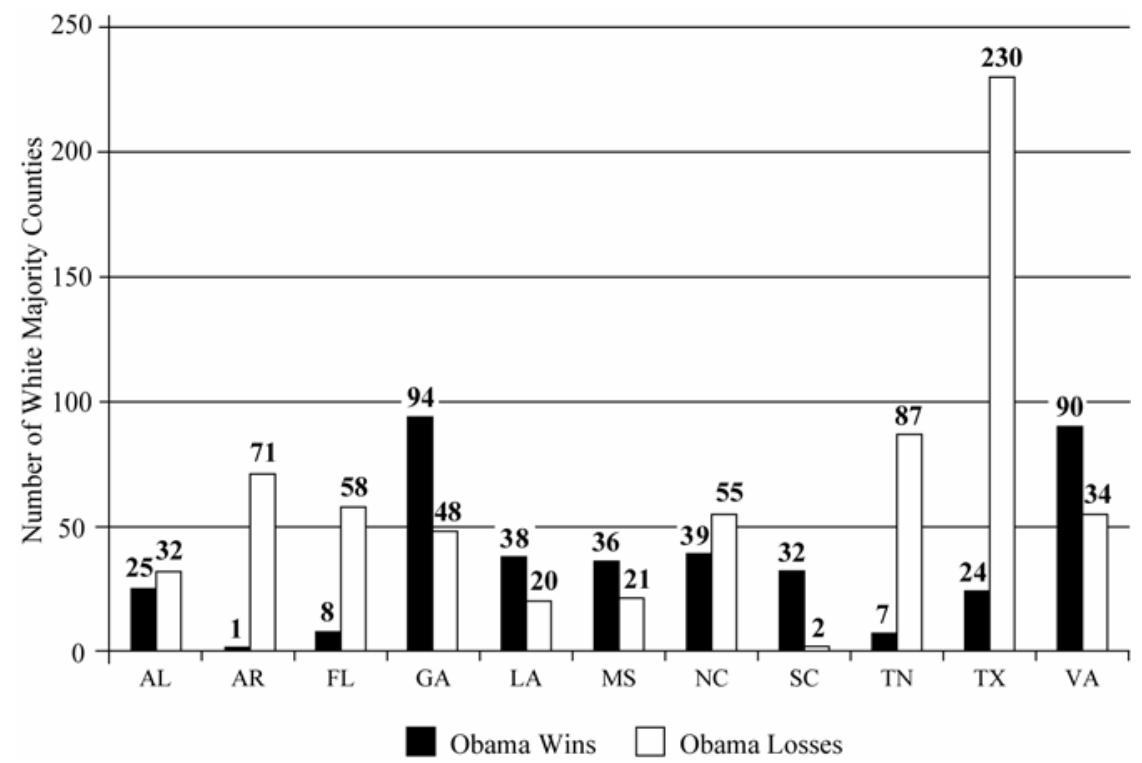


it lightly, while the Obama candidacy improves in the white counties over previous African American presidential candidates, there is still a very strong opposition to this candidacy.

Table 3 (2008) demonstrates that Senator Obama won nearly one hundred percent (99\%) of the African American majority counties while he won one-third (37.5\%) of the white majority and lost some two-thirds (62.5\%) of said counties in his initial election bid. Thus, there is still strong opposition to this African American presidential candidacy.

African American empowerment at the presidential level is, in this Third Reconstruction period, a problem for the two-thirds of the white southern electorate. And this should come as no significant finding at the moment simply because in this Third Reconstruction phase, African Americans hold essentially local, county and a few congressional offices as well as a very few statewide elective offices. And on this score they are about the same as the First and Second Reconstruction.

Resistance and opposition this time is coming from whites that by the end of the Second Reconstruction had realigned with the Republican Party. Most of the statewide officials are white Republicans as is the voting patterns of the white electorate. Secondly, the majority of southern congresspersons House and Senate are now Republicans. The rise of African American political empowerment via the Voting Rights Act and its extensions has led to the abandonment of the Democratic Party by the white southern electorate and the realignment with the Republican Party. And now African Americans have nearly taken over the southern Democratic Party by default.

But during the First and Second Reconstruction periods, the southern white party elites and masses took over the Democratic Party and left the African American party elites and electorate in the Republican Party. The empirical data generated from our analysis of African American presidential campaigns in the major parties reveals a pattern and tendency of party realignment based on race. The two electorates in the South realigned to political parties where the opposite racial group is not present in large numbers. And the other pattern and tendency is that there is at least in the First and Second and now the Third Reconstruction opposition to statewide African American candidates and particularly African American presidential candidates. Finally, from the 2008 presidential general election, we find that the opposition which is seen in the presidential primaries, is even stronger when it comes to the general election. The opposition becomes even more pronounced and dominant at the state-level. Although there is no data to compare 2008 with because there were no African American presidential nominees before then, in 2008 Obama won only four states: (1) Virginia, (2) Florida, and (3) North Carolina. 
Table 3. Performance of Barak Obama in Counties of the South 2008 Presidential Primaries

\begin{tabular}{|c|c|c|c|c|c|c|}
\hline \multirow[b]{2}{*}{ State } & \multirow{2}{*}{$\begin{array}{c}\text { Racial } \\
\text { Majority }\end{array}$} & \multicolumn{2}{|c|}{ Counties Won } & \multicolumn{2}{|c|}{ Counties Won } & \multirow{2}{*}{$\begin{array}{c}\text { Total } \\
\text { Number o } \\
\text { Counties }\end{array}$} \\
\hline & & Number & Percent & Number & Percent & \\
\hline \multirow[t]{3}{*}{ Alabama } & Black & 10 & $100 \%$ & 0 & $0 \%$ & 10 \\
\hline & White & 25 & $43.9 \%$ & 32 & $56.1 \%$ & 57 \\
\hline & Total & 35 & $52.2 \%$ & 32 & $47.8 \%$ & 67 \\
\hline \multirow[t]{3}{*}{ Arkansas } & Black & 2 & $66.7 \%$ & 1 & $33.3 \%$ & 3 \\
\hline & White & 1 & $1.4 \%$ & 71 & $98.6 \%$ & 72 \\
\hline & Total & 3 & $4.0 \%$ & 72 & $96.0 \%$ & 75 \\
\hline \multirow[t]{3}{*}{ Florida } & Black & 1 & $100 \%$ & 0 & $0 \%$ & 1 \\
\hline & White & 8 & $12.1 \%$ & 58 & $87.9 \%$ & 66 \\
\hline & Total & 9 & $13.4 \%$ & 58 & $86.6 \%$ & 67 \\
\hline \multirow[t]{3}{*}{ Georgia } & Black & 17 & $100 \%$ & 0 & $0 \%$ & 17 \\
\hline & White & 94 & $66.2 \%$ & 48 & $33.8 \%$ & 142 \\
\hline & Total & 111 & $69.8 \%$ & 48 & $30.2 \%$ & 159 \\
\hline \multirow[t]{3}{*}{ Louisiana } & Black & 6 & $100 \%$ & 0 & $0 \%$ & 6 \\
\hline & White & 38 & $65.5 \%$ & 20 & $34.5 \%$ & 58 \\
\hline & Total & 44 & $68.8 \%$ & 20 & $31.3 \%$ & 64 \\
\hline \multirow[t]{3}{*}{ Mississippi } & Black & 25 & $100 \%$ & 0 & $0 \%$ & 25 \\
\hline & White & 36 & $63.2 \%$ & 21 & $36.8 \%$ & 57 \\
\hline & Total & 61 & $74.4 \%$ & 21 & $25.6 \%$ & 82 \\
\hline \multirow{3}{*}{$\begin{array}{l}\text { North } \\
\text { Carolina }\end{array}$} & Black & 6 & $100 \%$ & 0 & $0 \%$ & 6 \\
\hline & White & 39 & $41.5 \%$ & 55 & $58.5 \%$ & 94 \\
\hline & Total & 45 & $45.0 \%$ & 55 & $55.0 \%$ & 100 \\
\hline \multirow{3}{*}{$\begin{array}{l}\text { South } \\
\text { Carolina }\end{array}$} & Black & 12 & $100 \%$ & 0 & $0 \%$ & 12 \\
\hline & White & 32 & $94.1 \%$ & 2 & $5.9 \%$ & 34 \\
\hline & Total & 44 & $95.7 \%$ & 2 & $4.3 \%$ & 46 \\
\hline \multirow[t]{3}{*}{ Tennessee } & Black & 1 & $100 \%$ & 0 & $0 \%$ & 1 \\
\hline & White & 7 & $7.4 \%$ & 87 & $92.6 \%$ & 94 \\
\hline & Total & 8 & $8.4 \%$ & 87 & $91.6 \%$ & 95 \\
\hline \multirow[t]{3}{*}{ Texas } & Black & 0 & $0 \%$ & 0 & $0 \%$ & 0 \\
\hline & White & 24 & $9.4 \%$ & 230 & $90.6 \%$ & 254 \\
\hline & Total & 24 & $9.4 \%$ & 230 & $90.6 \%$ & 254 \\
\hline \multirow[t]{3}{*}{ Virginia } & Black & 10 & $100 \%$ & 0 & $0 \%$ & 10 \\
\hline & White & 90 & $72.6 \%$ & 34 & $27.4 \%$ & 124 \\
\hline & Total & 100 & $74.6 \%$ & 34 & $25.4 \%$ & 134 \\
\hline \multicolumn{2}{|c|}{ Black County Totals } & 90 & $99 \%$ & 1 & $1 \%$ & 91 \\
\hline \multicolumn{2}{|c|}{ White County Totals } & 394 & $37.5 \%$ & 658 & $62.5 \%$ & 1052 \\
\hline \multicolumn{2}{|c|}{ Grand Totals } & 484 & $42.3 \%$ & 659 & $57.7 \%$ & 1143 \\
\hline
\end{tabular}


Having now discerned some key patterns and tendencies from the unique and rare 2008 presidential election contests we can now proceed to a theoretical analysis of the first and second concepts of Reconstruction and discern if these empirical regularities inform and/or relate to the theory building in the first and second concepts.

\section{Vann Woodward's Concept of the First Reconstruction}

Remarks and comments regarding the "New" or Second Reconstruction were present in the 1955 first edition of The Strange Career of Jim Crow, and were often made when Woodward discussed the First Reconstruction. He commented, "the New (or Second Reconstruction as he would eventually call it), unlike the old, was not the monopoly of one of the great political parties" (Woodward 1955, 10). To these insights he argued that "great impersonal forces of history . . . lay behind emancipation, the First Reconstruction, and Redemption. They included economic revolution, rapid urbanization, and war-war in a somewhat new dimension, called total war" (Woodward 1955, 10). Here, what he means is that a number of social forces generated and attained the reforms that came out of the First and Second Reconstructions.

Continuing his comparisons and contrasts, Woodward ventured the remark:

The New Reconstruction addressed itself to all the aspects of race relations that the first one attacked and even some that the First Reconstruction avoided or neglected. These included political, economic, and civil rights. Few sections of the segregation code have escaped attack, for the assault has been leveled at the Jim Crow system in trains, buses, and other common carriers; in housing and working conditions; in restaurants, theaters, and hospitals; in playgrounds, public parks, swimming pools, and organized sports to mention a few examples. Most recently the attack has been carried into two areas in which the First Reconstruction radicals made no serious effort: segregation in the armed services and in the public schools (Woodward 1955, 11).

Woodward explains that the First Reconstruction avoided two distinct areas of public and private life for systematic reform, public schools and the armed services. As he saw it, this was one of the major differences between the two different stages in southern history.

Woodward did not stop with these exceptions and differences in regard to the First Reconstruction; in fact, he expanded upon them. Accordingly, Woodward saw some of the roots of segregation inside the First Reconstruction. He found "some important aspects of segregation were achieved and sanctioned by the First Reconstruction. One of these was segregation of the great Protestant churches, a process accomplished by the voluntary with- 
drawal of the Negroes and their establishment of independent organizations" (Woodward 1955, 15). Secondly, he wrote that "segregation became the almost universal practice in the public schools of the South during Reconstruction, with or without explicit sanction of the radicals" (Woodward 1955, 15). This was followed by description of a third major characteristic of the First Reconstruction. In "the military services, segregation was strengthened by the Civil War and left unaltered during (First) Reconstruction" (Woodward 1955, 15). And finally, there was a fourth characteristic of the First Reconstruction: "Equality in social gatherings of a private nature, there is little evidence that even the high Negro officials of the (First) Reconstruction governments in the South were extended that recognition-even by the white radicals" (Woodward 1955, 15).

With these remarks and comments, Woodward had offered all of the incisive and insightful reflections about the concept of the First Reconstruction in the initial edition. More remarks and comments would be forthcoming in the second edition of the book two years later. And in this 1957 edition, Woodward expanded upon his partisanship linkage made in the 1955 book. In a new Chapter to the second edition, he found that "Reconstruction in the 1860's and '70's was pretty strictly identified in origin, implementation, and execution with the Republican Party, and about as consistently opposed by the Democratic Party" (Woodward 1957, 174). To these new reflections he went even further: "The creation of a large new electorate devoted to the Republicans and the simultaneous crippling of an electorate equally devoted to the Democrats was one meaning of Reconstruction, the crude political meaning" (Woodward 1957, 174-75). And this meant "whatever the merits of the reconstruction plan in terms of justice, principle, and human rights, its success spelled political advantage for one party and disadvantage for the other” (Woodward 1957, 174).

Finally, Woodward closes out his expanded discussion of the First Reconstruction by further expanding on an earlier comment on churches by saying that "the First Reconstruction tended to widen instead of close the sectional breach that had opened with the great national church organizations in the ante-bellum struggle over slavery" (Woodward 1957, 176). Simply put the northern and southern branches of the very same religious churches during this period were now taking opposite positions on slavery.

Since both of Professor Woodward's definition and conceptualization of the First Reconstruction emerged and evolved from specific and/or comparative and contrasting remarks, a composite portrait of this First Reconstruction would have to be used in order to be comprehensive and systematic. Thus, as Woodward's comments, remarks and insights reveal, he saw a reform movement emerging in the South in the period 1865-1877the period of the First Reconstruction - that included efforts by the federal 
government in the form of Congressional Reconstruction, along with the Republican Party in the South, and African American Republicans and voters assisted by local whites, to institutionalize needed and necessary reforms. The scope of these reforms was limited rather than broad based because they failed to reform the school system and the federal military. However, these two major societal organizations, one local, i.e., the school system and the other national, the U.S. military, left huge areas of the southern states segregated.

Then, another major societal organization, "Protestant Churches" which had helped to launch, promote and sustain the emerging reform movement failed to desegregate from within and therefore abetted the rise of segregation by allowing the African American community to establish their own separate African American churches both North and South. Hence, the churches, which were both national and local in scope, became ironically one of the roots and pillars of the eventual system of segregation in the South along with the schools and the military. Churches in this fashion worked to undercut the very thing, which they had been working to avoid, a desegregated society. And this renders the reform movement only a partial one.

Next, Professor Woodward not only saw the churches as having a flawed strategy and program during the First Reconstruction period (18651877) but also the political parties. He bemoans the fact the only one political party embraced and pushed the reforms, the Republican Party and even this inclusionary effort was half-hearted. In his description of the political parties, he found that even the Republican Party socially isolated even the black elected Republican officials and snubbed them. Although, he does not say it in his specific discussion of the First Reconstruction, he does indicate that the party relegated Black Republicans to only minor elective offices and a few major elective and appointive offices when they could not absolutely avoid it.

In Professor Woodward's concept of the First Reconstruction (18651877), the Presidential Reconstruction efforts of both President Abraham Lincoln and Andrew Johnson were arrayed against reform. To be balanced, they were in both camps, i.e. support for reform and against some aspect of the reform. Both men were for limited suffrage rights, suffrage rights with an educational qualification. And eventually, Johnson was even opposed to that, coming out during his administration against suffrage rights altogether. And Presidential Johnson's stand emboldened southern states to also oppose suffrage rights for the Freedmen, and they, in turn, did not grant these rights when President Johnson restored them back to the Union.

Congress had gone along with this approach when they passed the First Military Reconstruction Act of 1867 because it left the granting of suffrage 
rights up to the ten southern states. When not a single one of the ten states complied with the law, Congress passed the Second Military Reconstruction Act of 1867 giving the U.S. Military Commanders the right to register both Freedmen and whites, hold a state constitutional convention, draft a new state constitution that gave the Freedmen the right to vote and then hold elections for the new state governments (McPherson 1982, 524).

The other principal force arrayed against this First Reconstruction was the Democratic Party (known initially as White Conservatives). When reconstituted the southern Democratic Party became the dominant party in the region. Of how this party eventually arrived at this position, Professor Woodward writes "it would be a mistake to picture the Democratic Redeemers as the first Southern whites to appeal successfully to the Negro voter with the conservative race philosophy. That distinction belongs to the conservative ex-Whigs planters of Mississippi, turned Republicans, who took over the party from the radicals and dominated it for several years with Negro support" (Woodward 1955, 33). And when this group of White conservative leaders returned en masse to the Democratic Party these

\begin{abstract}
Southern whites accept them (Freedmen voters) precisely as Northern men in cities accept the ignorant Irish vote, - not cheerfully, but with acquiescence in the inevitable; and when the strict color-line is once broken they are just as ready to conciliate the negro as the Northern politician to flatter the Irishman (Woodward 1955, 55).
\end{abstract}

At this point, Woodward concludes: "as a voter the Negro was both hated and cajoled, both intimidated and courted, but he could never be ignored so long as he voted," by the southern Democratic party (Woodward 1955, 55). Thus, when the opportunity came, this party moved in the late 1880s and 1890 to completely disenfranchise this voter. This party ultimately impeded and helped to eliminate the reform both nationally and regionally. At the national level under the divided terms of Democrat Grover Cleveland, the party literally removed almost all of the suffrage rights laws written during the reform thrust of the First Reconstruction. Thus, Woodward does not say it explicitly, yet we find it in our empirical analysis of the major event of the Third Reconstruction, racial party realignments that eventually undercut the reform effort and set in motion the next needed reform.

Military Commanders, who helped to carry out the reforms, were not always in agreement with them and only partially implemented them. This was helped by Republican President Grant who came out publicly opposed to the 15th Amendment. Such national and local activity by the military ensured poor implementation and, at best, curtailed the reforms of the First Reconstruction. And when these forces that were arrayed against the reforms are joined with the Democratic Redeemers recapture of the southern govern- 
ments away from the reformers and allowed them to pursue their own local strategy in dealing with the so-called race problem in the political deal granted by Republican President R.B. Hayes in the Compromise of 1877, the First Reconstruction collapsed.

But it was not just these sundry political leaders, national and local forces undermining the First Reconstruction there was also the matter of the rebirth of the Ku Klux Klan and numerous local offshoot organizations that wage extralegal violence to assist the white Democratic Redeemers in maintaining their recaptured power. And to ensure that the white masses went along with this recapture and the violence that was needed to sustain it led to the emergence of a new ideology known as "White Supremacy." Soon this ideology was pervasive enough so that it captured the public opinion of the region, helping to institutionalize a new socio-economic and political system known as segregation.

According to Woodward, segregation had its roots in the First Reconstruction and it was this ever rising and omnipresent system that ensured that the First Reconstruction would came to an end and set in motion the need for a Second Reconstruction.

\section{Vann Woodward's Concept of the Second Reconstruction}

C. Vann Woodward first used the term "Second Reconstruction" in his article "The Political Legacy of Reconstruction," which appeared in the special summer 1957 issue of the Journal of Negro Education. Editor Charles Thompson wrote

each summer the Journal of Negro Education publishes a Yearbook on some specific problem dealing with the life and education of the Negro or some other minority group. The 1957 Summer Yearbook is devoted to a discussion of the Negro voter in the South, and of some of the educational implications involved (Thompson 1957, 213).

According to Editor Thompson, he had divided the Yearbook into five key parts. The second section provides a brief historical overview of the First Reconstruction and the first chapter in this second section began with Professor Woodward's article "The Legacy of Reconstruction. And it is in this article that Woodward "indicates how the Negro obtained the vote, how it was practically lost through revolution and political compromise, and what effect this history has had upon the current situation" (Thompson 1957, 217). Overall, Editor Thompson was making an attempt at a comprehensive and systematic study of the African American electorate in the South after the 1956 presidential election, the first such effort since the Supreme Court's historic decision on Brown v. Board of Education. Not only had Professor 
Woodward prepared a legal brief for this landmark case but also, almost all of the major participants in that court case wrote articles in this Yearbook volume.

Of the twenty-three articles, there were twenty-six participants and among the contributors were the Executive Secretary of the NAACP, Roy Wilkins, Public Relations Director of NAACP, Henry Lee Moon, and Attorneys Thurgood Marshall and James Nabrit, Jr., who had helped to argue the Brown case before the Supreme Court. And beyond such notable African American professors who contributed was historian John Hope Franklin, who also had provided a legal brief and Clarence Bacote, sociologists Henry Lee Bullock, Tilman Cothran, and Charles G. Gomillion, political scientists Earl Lewis and I.G. Newton; State and local government officials Robert Weaver, and James T. McCain; and Research at the Southern Regional Council, Florence Irving, to name just a few key people. And also among this list were several white scholars and activists, like Woodward, political scientists John Fenton at Tulane, and Donald Strong at University of Alabama and the well-known political journalist Samuel Lubell.

In his article, Professor Woodward had this to say about his innovative and inventive concept:

During the present struggle for Negro rights, which might even be called the Second Reconstruction-though one of a different sort-I have noticed among Negro intellectuals at times a tendency to look back upon the First Reconstruction as if it were in some ways a sort of Golden Age. In this nostalgic view that period takes the shape of the race's finest hour, a time of heroic leaders and deeds, of high faith and firm resolution, a time of forthright and passionate action, with no bowing to compromises of 'deliberate speed.' I think I understand their feeling. Reconstruction will always have a special and powerful meaning for the Negro. It was undoubtedly a period full of rich and tragic and meaningful history, a period that has many meanings yet to yield. But I seriously doubt that it will ever serve satisfactorily as a golden Age-for anybody. There is too much irony mixed with the tragedy for that (Woodward 1957, 240).

Although he formally launches the concept of the Second Reconstruction in the last paragraph in the article, he provided this article to a much larger audience when he placed it three years later in 1960 in his popular collection of essays The Burden of Southern History as Chapter Five. Nevertheless, the forerunner of the concept of the Second Reconstruction actually appeared in 1955 in the initial edition of The Strange Career of Jim Crow, as the "New Reconstruction” (Woodward 1955, 10).

Historian and critic Howard Rabinowitz explains that "Woodward was even more sympathetic to the aims, legacy, and problems of the First Reconstruction in an article that also marked his full commitment to the term 
Second Reconstruction.” Moreover, in the very same year that he mentioned the concept he brought out in 1957 a revised second edition of his popular The Strange Career of Jim Crow, which includes a fourth Chapter entitled: 'Deliberate Speed' vs. "Majestic Instancy." And in this chapter Professor Woodward almost fully embraces the concept that he announced in the Journal article and in his rather extended discussion uses it to displace this initial phrasing with the term "New Reconstruction." New is now nearly gone and the Second Reconstruction becomes the standard usage. The concept is now formally announced and thrusted simultaneously upon both the academic and scholarly and the lay and general reading public audiences.

Again, Professor Rabinowitz comments on the evolution and transition of Woodward from the "New" to the Second Reconstruction concept. He writes: "in his view, the nation in 1955 was in the midst of a 'New Reconstruction,' a term later used interchangeably with 'Second Reconstruction,' until the latter unaccountably replaced 'New Reconstruction' in the 1966 edition,” of the Strange Career (Rabinowitz 1997, 191). In the 1957 edition, Second Reconstruction is used jointly but more often in the new chapter but it does not replace the use of "New Reconstruction" in this and/or in the initial chapter. Hence, there is at least mixed usage in the 1957 edition. The evolution of the concept was already underway when it was announced in the 1957 journal article.

Of his remarks and comments in the 1957 edition of the Strange Career, Woodward began as he did in the earlier edition with a comparison and contrast statement. Writing on the matter he opined, "already the Second Reconstruction could be claimed to have accomplished more genuine change in some aspects of human relations than the First Reconstruction had done with all its blood and thunder and histrionics" (Woodward 1957, 155). Later in the chapter he adds more insights about the concept by saying: "in this mood and in view of prevailing retrogression, it is natural to speculate whether the New Reconstruction, in spite of its promising start, is not doomed to repeat the frustration and failure of the First Reconstruction" (Woodward 1957, 169).

After these opening remarks and comments, Woodward quickly comes back to make some remarks and comments about the First Reconstruction. He suggests that "the revolutionary architects of the First Reconstruction, moreover, were untroubled with scruples about state rights and quite ready to use force without stint to accomplish their purposes" (Woodward 1957, 170). According to Woodward, as the white conservative Democratic Redeemers saw it, "if the Constitution got in their way they changed it or ignored it, and they took much the same attitude toward the President and Supreme Court" (Woodward 1957, 170). Such a political will allowed that "the will of the defeated, discredited and for a time, helpless South to 
prevail" over the reformers and their achievements (Woodward 1957, 17071). Such was the outcome of the First Reconstruction.

Professor Woodward offers more detail about the First Reconstruction seemingly to instruct the reader about the Second Reconstruction. He says, "for the national background of the First Reconstruction was the Gilded Age. It also was a postwar era that, after a few years of peace, had had enough of idealism, self-sacrifice and crusades and was exuberantly preoccupied in material things and self-indulgence" (Woodward 1957, 173). After these additional insights about the First Reconstruction, he quickly returns to remarks and comments about the Second Reconstruction.

The Second Reconstruction has no such strongly marked partisan character. It originated under the leadership of one party and was continued by the other. It has received important contributions and encouragement from both . . . the success of the Second Reconstruction is not tied to the fortunes of one political party" (Woodward 1957, 175).

Unlike in the First Reconstruction where both the northern and southern sections of the Democratic party were of like minds on the southern Negro question and the South's approach to it, in the 1950s and 1960s there was an evolving intra-party struggle going on in the Democratic party where not only were northern party elites opposed to the southern Democratic party efforts to deny the African American electorate civil and suffrage rights, but also the white electorate as well. And one of the reasons for this reality is that the African American electorate that had migrated out of the South into the large northern industrial states that had significant electoral votes had become something of a balance-of-power force in helping the Democratic party win post-war presidential elections with Truman in 1948, and Kennedy in 1960 (Moon 2005). Here without saying it, Woodward is showing that the African American migration to the northern states eventually permits a racial party realignment but this time they are realigning into the party of the southern whites. This helps to set the stage for the central defining feature and characteristic of the Third Reconstruction.

Writing further Woodward argues that in "the Second Reconstruction . . . the defection of the Border States from the cause of segregation is becoming more and more apparent ... (and) ... each month brings news of additional retreats along the segregation front” (Moon 2005, 178). With this view and perspective on the Second Reconstruction, Woodward predicts "in spite of resistance and recent setbacks, therefore, the preponderant evidence points to the eventual doom of segregation in American life and the triumph of the Second Reconstruction-in the long run" (Moon 2005, 178-79). And this comment led Woodward to make his final remark about the Second Reconstruction. Woodward declares: 
but the 'long run' implies 'gradualism,' and 'gradualism' is a word that has acquired almost as evil associations as the word 'appeasement' once had. ... Undesirable or not, gradualism is an inescapable fact and a basic characteristic of the New Reconstruction.

Accordingly, for Woodward, this gradualism holds the seeds to the possible failure of the reform thrust embedded in the Second Reconstruction. And this then sets the stage for the emergence of the Third Reconstruction.

In this Second Reconstruction concept, at the theoretical level, one sees what we found in our empirical analysis, race based partisanship in the South and the African American and White partisans are attached to different parties and party movement is in the opposite direction and at great odds, if not in electoral conflict with each other. Thus, to fully grasp and understand the role of race in regional partisanship realignment one needs to see it in the theoretical context of Woodward's first, second and third concepts. And it is now necessary to acknowledge the reality that it is pertinent to all three concepts as well as the connecting linkage and relationship.

\section{Summary and Conclusions}

Professor Woodward's conceptualization about the Third Reconstruction is at this writing incomplete in terms of definition, and especially in terms of a periodization. There is in the period from 1966 through the present no major reform event and/or events with the exception of the renewal of the Voting Rights Act in 2006. No major leader replaced King, except Reverend Jackson and he did so in the electoral arena. Following Jackson has been the election of the first African American president Barack Obama. The majority of whites in either the nation and especially in the South did not vote for him and since being in office, opposition has come from all regions of the country. And while some of this opposition has evolved supposedly as a consequence of his economic policies and high employment, all of the polls taken before he took office and particularly in the majority of the states of the old South revealed significant opposition to him because of his race. And while he did win three states in the region, Florida, North Carolina, and Virginia in many of the other southern states the white support for the Republican Party grew over what it had been four years earlier.

With these new realities streaming from the struggle of African American empowerment at the national level many in the aftermath of President Obama declared that the nation had now passed into what they dubbed postracial America. As a consequence, numerous African American candidates entered the 2010 southern Democratic primaries seeking nominations for a variety of statewide offices. The vast majority lost to white candidates and where they did not, the African American electorate secured the nomination 
for them due to the fact that the white electorate in the South is no longer voting in the Democratic parties. Thus, a few African American statewide candidates won the party's nomination and will face Republicans in the forthcoming general elections in November. Their chances are quite bleak due to the fact that the white electorate is voting Republican and in every increasing numbers. This means that the chances and/or victories for the African American Democratic statewide candidates are near impossible unless some political crossover voting takes place (Bositis 2010).

Therefore, the Third Reconstruction now faces a vastly different political party situation in terms of the "party-in-the-electorate" in the region. Neither the First nor the Second Reconstructions faced these phenomena. And Professor Woodward did not attempt of theorizing on this point of racial partisanship in the region. The empirical evidence not only finds it but sees it as the dominant characteristic and suggests that Woodward's theorizing implies it. Nor had it appeared in the past. Therefore, we know that any reform during this period must address not only this issue but a rising new one known as felony disenfranchisement that appeared in Florida during the 2000 contested presidential outcome in the State. New congressional legislation did come forth to deal with the problems inherent in electoral administration known as the HAVA Act. But this reform legislation did not address the larger problem of felony disenfranchisement that has been targeted toward members of the African American electorate (Hull 2006; Manza and Uggen 2008). Clearly, there is much to consider before the scholarly community can properly conceptualize Woodward last great idea and term, the Third Reconstruction. Hopefully, there are enough intriguing and revealing insights to launch a new series of fruitful investigations into Woodward's rich constellation of ideas about the South, African Americans and political partisanship in the region to say nothing of his three concepts of Reconstruction.

\section{REFERENCES}

Bositis, David. 2010. In Anticipation of November 2: Black Voters and Candidates and the 2010 Midterm Elections. Washington, DC: Joint Center for Political and Economic Studies.

Deskins, Jr., Donald R., Hanes Walton, Jr., and Sherman C. Puckett. 2010. Presidential Elections, 1789-2008: Mapping County, State and National Election Data. Ann Arbor: University of Michigan Press.

Hull, Elizabeth. 2006. The Disenfranchisement of Ex-Felons. Philadelphia, PA: Temple University Press.

Kousser, J. Morgan, and James McPherson. 1982. Introduction: C. Vann Woodward: An Assessment of His Work and Influence. In Region, Race, and Reconstruction: 
Essays in Honor of C. Vann Woodward, eds. J. Morgan Kousser and James McPherson. New York: Oxford University Press.

Leuchtenburg, William. 2008. Foreword. In The Burden of Southern History, 3rd ed., C. Vann Woodward. Baton Rouge: Louisiana State University Press.

Manza, Jeff, and Christopher Uggen. 2008. Locked Out: Felony Disenfranchisement and American Democracy. New York: Oxford University Press.

McPherson, James. 1982. Ordeal by Fire: The Civil War and Reconstruction. New York: Alfred Knopf.

Moon, Henry Lee. 1948. Balance of Power: The Negro Vote. Garden City, NY: Doubleday.

Rabinowitz, Howard. 1997. More Than the Woodward Thesis: Assessing the Strange Career of Jim Crow. In C. Vann Woodward: A Southern Historian and His Critics, ed. John Herbert Roper. Athens: University of Georgia Press.

Roper, John Herbert. 1987. C. Vann Woodward, Southerner. Athens: University of Georgia Press.

Thompson, Charles. 1957. Editorial Comment: The Negro Voter in the South. Journal of Negro Education 26:213.

Valelly, Richard. 2004. The Two Reconstructions: The Struggle for Black Enfranchisement. Chicago: University of Chicago Press.

Walters, Ronald. 2005. Freedom is Not Enough: Black Voters, Black Candidates, and American Presidential Politics. Lanham, MD: Rowman \& Littlefield.

Walton, Jr., Hanes. 2000. Reelection. New York: Columbia University Press.

Walton, Jr., Hanes, Josephine A.V. Allen, Sherman C. Puckett and Donald R. Deskins, Jr. 2010. Black Politicians: Paving the Way. In African Americans and the Presidency: The Road to the White House, eds. Bruce Glasrud and Cary D. Wintz. New York: Routledge.

Walton, Jr., Hanes, and Spence Lester. 1999. African American Presidential Convention and Nomination Politics: Alan Keyes in the 1996 Republican Presidential Primaries and Convention. National Political Science 7:188-209.

Woodward, C. Vann. 1955. The Strange Career of Jim Crow. New York: Oxford University Press.

Woodward, C. Vann. 1957. The Political Legacy of Reconstruction. Journal of Negro Education 26:240.

Woodward, C. Vann. 1957. The Strange Career of Jim Crow, New and Revised Edition. New York: Oxford University Press.

Woodward, C. Vann. 1960. The Age of Reinterpretation. American Historical Review 66:1-19.

Woodward, C. Vann. 2008. The Burden of Southern History, 3rd ed. Baton Rouge: Louisiana State University Press. 